\title{
Luteal LH receptors during the oestrous cycle and early pregnancy in the pig*
}

\author{
A. Ziecik $\dagger$, H. J. Shaw $\ddagger$ and A. P. F. Flint \\ A.R.C. Institute of Animal Physiology, Babraham, Cambridge CB2 4AT, U.K.
}

\begin{abstract}
Summary. The concentration, affinity constant and occupancy of the LH receptor have been measured in corpora lutea, from 29 pigs at Days 6-16 of the oestrous cycle, and from 25 pigs at Days $12-30$ of pregnancy, by using ${ }^{125}$ I-labelled porcine $\mathrm{LH}$ tracer. Investigation of the specificity of the receptor showed that cross-reactions of other pituitary hormones were accounted for by their contamination with $\mathrm{LH}$. Luteal concentration of unoccupied receptors doubled between Days 6 and 10 of the cycle, and decreased between Days 12 and 14; it increased 3-fold between Days 20 and 30 of pregnancy, but was lower on Day 12 of pregnancy than at a comparable stage of the cycle. Concentrations of receptors occupied by LH increased early in the oestrous cycle, in parallel with the total receptor concentration; in pregnancy the percentage occupancy dropped dramatically as total receptor concentration increased between Days 20 and 30. Receptor affinity constants increased towards the end of the cycle and decreased between Days 20 and 30 of pregnancy. It is suggested that (1) the lower concentration of receptors in early pregnancy may reflect down regulation by circulating $\mathrm{LH}$, concentrations of which are higher in early pregnancy than during the cycle; (2) the increase in receptor concentration between Days 20 and 30 of pregnancy may be due to a rise in circulating oestrogen levels; and (3) the decrease in occupancy at this time may be caused either by a decrease in affinity constant or by placental production of a chorionic gonadotrophin-like compound.
\end{abstract}

\section{Introduction}

The interaction of luteinizing hormone $(\mathrm{LH})$ with its receptor on the luteal cell is important in the regulation of the function of the corpus luteum in domestic species (Niswender, Menon \& Jaffe, 1972; Hansel, Concannon \& Lukaszewska, 1973; Nalbandov, 1973). Watson \& Leask (1975) and Lemon \& Loir (1977) showed that LH stimulated the synthesis of progesterone by porcine luteal slices and dissociated luteal cells, indicating that, at least in vitro, the concentration of $\mathrm{LH}$ to which the cells are exposed is important in determining its stimulatory effect. Diekman, O'Callaghan, Nett \& Niswender (1978a) suggested that in ewes the number of receptors occupied by LH increased during the mid-luteal phase of the oestrous cycle, as a result of an increase in total LH receptor numbers; this increase in occupied receptors was shown to correlate with enhanced progesterone secretion. Knowledge of the properties of the LH receptor

* Reprint requests to Dr A. P. F. Flint, A.R.C. Institute of Animal Physiology, Babraham, Cambridge CB2 4AT, U.K.

$\dagger$ Present address: Institute of Animal Physiology \& Biochemistry, University of Agriculture \& Technology, 10-718 Olsztyn, Poland.

† Present address: National Institute for Biological Standards and Control, Holly Hill, Hampstead, London NW3 6RB, U.K. 
may therefore be important in relation to luteal function during luteolysis (Henderson \& McNatty, 1975) and the establishment of pregnancy (Flint, Gadsby \& Heap, 1979). The LH receptor of the granulosa cell (Kammerman, Canfield, Kolena \& Channing, 1972; Lee, 1976; Nakano, Akahori, Katayama \& Tojo, 1977) and the prolactin receptor of the corpus luteum (Rolland, Gunsalus \& Hammond, 1976) have been studied in detail in pigs, but the luteal LH receptor appears to have received less attention. The purpose of the present experiments was to measure and characterize the porcine luteal $\mathrm{LH}$ receptor, and to determine its occupancy by $\mathrm{LH}$ at various stages of the oestrous cycle and early pregnancy.

\section{Materials and Methods}

Hormone preparations. Purified porcine LH (LH-GPZ-1; potency $0.63 \times$ NIH-LH-S1) was that described by Ziecik, Goralska, Krzymowski \& Pogorzelski (1978); hCG (CR-119, 11600 i.u./mg) was the gift of the Center for Population Research of the National Institute of Child Health and Human Development, National Institutes of Health, Bethesda, Maryland, U.S.A. Porcine GH (NIH-GH-P501-26B), bovine TSH (NIH-TSH-B3, LH content $0.04 \times \mathrm{NIH}-$ LH-S1), bovine LH (NIH-LH-B4, 0.94 $\times$ NIH-LH-S1) and ovine FSH $(0.013 \times$ NIH-LH-S1), were from the Pituitary Hormone Distribution Program, National Institute of Arthritis, Metabolic and Digestive Diseases, National Institutes of Health, Bethesda. Porcine prolactin was purified by $\mathrm{K}$. Kochman (preparation KK-2; LH content not determined) and porcine FSH (LH content approximately $0.02 \times \mathrm{NIH}-\mathrm{LH}-\mathrm{S} 1$ ) was prepared by $\mathrm{Dr} \mathrm{M}$. Goralska, of the Institute of Animal Physiology and Biochemistry, Olsztyn, Poland.

Preparation of receptors. Corpora lutea were dissected from ovaries obtained at the slaughter of 29 cyclic and 25 pregnant Large White sows from one of the Institute's herds. Early pregnancy was verified by flushing blastocysts from the uteri; the first day of oestrus was designated Day 0 of the cycle or pregnancy.

Corpora lutea were trimmed of connective tissue, weighed, minced with scissors and homogenized at $4{ }^{\circ} \mathrm{C}$, using a Polytron homogenizer, for $10-15 \mathrm{sec}$ in 4 volumes $(\mathrm{ml} / \mathrm{g})$ of 0.25 $\mathrm{M}$-sucrose containing $25 \mathrm{mM}$-Tris- $\mathrm{HCl}, \mathrm{pH} \mathrm{7.4}$. The homogenate was filtered through 4 layers of cheesecloth and the filtrate was centrifuged for $20 \mathrm{~min}$ at $800 \mathrm{~g}$. The resulting supernatant was centrifuged further for $1 \mathrm{~h}$ at $27000 \mathrm{~g}$, and the sediment was suspended in $1 \mathrm{ml}$ ice-cold 25 mM-Tris- $\mathrm{HCl}, \mathrm{pH} 7 \cdot 2$, containing $0 \cdot 1 \%$ bovine serum albumin and $5 \mathrm{mM}-\mathrm{MgCl}_{2}$; after dividing into $0.5 \mathrm{ml}$ samples, the resulting suspension was stored in liquid nitrogen. A fraction of receptor preparation was assayed for protein by the method of Lowry, Rosebrough, Farr \& Randall (1951). Preliminary experiments showed that LH binding activity was present in fractions sedimenting over a wide range of centrifugal forces; preparation of receptor fractions by sequential centrifugation of homogenates at 500,2000,10000,30000 and $110000 \mathrm{~g}$ yielded pellets with essentially identical binding activity per mg protein. However, the pellet obtained at $500 \mathrm{~g}$ was relatively unstable during subsequent centrifugation to separate bound and free hormone after incubation. Binding activity was stable for up to 6 months in corpora lutea stored in liquid nitrogen before extraction, but was reduced by more than $80 \%$ during storage at $-15^{\circ} \mathrm{C}$ for 1 month.

Radioiodination of porcine $L H$. LH-GPZ-1 was labelled using chloramine $\mathrm{T}$ by the method of Greenwood, Hunter \& Glover (1963) as modified by Catt \& Dufau (1975). Iodinated hormone was purified on columns $(1 \times 3 \mathrm{~cm})$ of dry Whatman CF-11 cellulose; intact ${ }^{125} \mathrm{I}$-labelled $\mathrm{LH}$ was obtained in $91-95 \%$ yield with specific activity in the range $25-40$ $\mu \mathrm{Ci} / \mu \mathrm{g}$. The iodinated material was stored at $4{ }^{\circ} \mathrm{C}$ in the presence of $0.1 \%$ sodium azide, and was stable for up to 3 weeks.

Measurement of unoccupied $L H$ receptor concentration and affinity constant. The cell membrane fraction was incubated with ${ }^{125}$ I-labelled $_{\text {e }}$ porcine ${ }_{10} \mathrm{LH}_{\mathrm{n}} \mathrm{H}_{1}$ polystyrene $_{26}$ tubes $\mathrm{i}_{2}$ the 
incubation mixture consisted of: $0.1 \mathrm{ml} 25 \mathrm{~mm}$-Tris- $\mathrm{HCl}, \mathrm{pH} 7.2$, containing $5 \mathrm{mM}-\mathrm{MgCl}_{2}$ and $0.1 \%$ bovine serum albumin (incubation buffer); $0.1 \mathrm{ml}$ incubation buffer containing various amounts of porcine LH; $0.1 \mathrm{ml}$ incubation buffer containing $20000-30000$ counts ${ }^{125}$ I-labelled $\mathrm{LH} / \mathrm{min}$, and $0.2 \mathrm{ml}$ receptor preparation containing $0.4 \mathrm{mg}$ protein. The samples were incubated overnight at room temperature. To separate receptor-bound from free ${ }^{125} \mathrm{I}$-labelled $\mathrm{LH}, 1.5 \mathrm{ml}$ ice-cold incubation buffer were added, and the tubes were centrifuged at $1000 \mathrm{~g}$ for $30 \mathrm{~min}$; the supernatants were removed by aspiration and the pellets counted for ${ }^{125} \mathrm{I}$ using an LKB Wallac 80000 gamma counter (efficiency 58\%). Centrifugation under these conditions sedimented more than $90 \%$ of the bound ${ }^{125} \mathrm{I}$-labelled $\mathrm{LH}$ that was precipitated by centrifugation at $27000 \mathrm{~g}$ for $\mathrm{I}$ h. Preliminary experiments showed that binding of labelled LH was proportional to the amount of receptor added, up to $1.0 \mathrm{mg}$ protein. Nonetheless $0.4 \mathrm{mg}$ receptor protein was consistently used to determine binding parameters, and values obtained were normalized to a per mg basis for presentation (Chamness \& McGuire, 1975).

Non-specific binding determined in the presence of excess $(1 \mu \mathrm{g} / \mathrm{tube})$ unlabelled $\mathrm{LH}$ was usually $<3 \%$ of the total ${ }^{125}$ I-labelled LH added. Concentration of unoccupied binding sites, and affinity constants $\left(K_{\mathrm{a}}\right)$ were determined by Scatchard analysis; 8 or 9 sub-saturating quantities of unlabelled porcine $\mathrm{LH}$ were used for each receptor preparation (in the range $0 \cdot 17-50 \mathrm{ng} / \mathrm{tube}$, each concentration in triplicate). Affinity constants calculated by Scatchard analysis were shown to be unaffected by alterations in receptor protein concentration in the range $0.15-0.65$ $\mathrm{mg} /$ tube. For calculation purposes the molecular weight of porcine LH was assumed to be 28000 (Reichert \& Jiang, 1965). This method measures unoccupied receptor concentrations; occupied receptors are assumed to be unavailable for binding to labelled ligand, since dissociation from them is slow. Even if the generation of unoccupied receptors from occupied receptors by dissociation occurred during incubation, however, the effect on unoccupied receptor concentration would be negligible, because the proportion of receptors occupied is low.

Three experiments were carried out to investigate whether binding parameters were influenced by degradation of ${ }^{125} \mathrm{I}$-labelled $\mathrm{LH}$ during incubation. (1) Inclusion of the protease inhibitors, L-1-tosylamide-2-phenylmethylchloromethyl ketone (TPCK; $1 \mathrm{mM}$ ), $N$ - $\alpha$-p-tosylL-lysine chloromethyl ketone (TLCK; $1 \mathrm{mM}$ ), phenylmethyl sulphonyl fiuoride (PMSF; $1 \mathrm{mM}$ ), leupeptin $(0.44 \mathrm{mM})$, soybean trypsin inhibitor $(0.1 \%)$ or crude ovalbumin $(0.1 \%)$ in the incubation buffer was shown to affect neither the concentrations nor affinity of receptors. (2) Submitting ${ }^{125} \mathrm{I}$-labelled $\mathrm{LH}$ that remained unbound by receptors after overnight incubation to gel filtration on columns of Sephadex G-100 demonstrated no detectable formation of ${ }^{125}$ I-labelled fragments of low molecular weight. (3) Binding ${ }^{125}$ I-labelled LH that initially remained unbound in a second overnight incubation with $0.4 \mathrm{mg}$ membrane protein showed that $>60 \%$ of the remaining tracer was capable of interacting with receptor, despite standing at room temperature for nearly $48 \mathrm{~h}$.

Elution of endogenous $\mathrm{LH}$ from luteal cell membrane preparations. In preliminary experiments we attempted to dissociate ${ }^{125}$ I-labelled $\mathrm{LH}$-receptor complexes by incubation with $4 \mathrm{M}$-urea (Halme, Ikonen, Rutanen \& Seppälä, 1978), $0 \cdot 15 \mathrm{M}-\mathrm{NaCl}$ titrated to $\mathrm{pH} 2 \cdot 3$ with $\mathrm{HCl}$ (Dufau, Catt \& Tsuruhara, 1972), 0.1 N-formic acid (Diekman et al., 1978a) and (as a control) Tris- $\mathrm{HCl}$ buffer. After overnight incubation with gentle stirring at $4^{\circ} \mathrm{C}$, elution efficiencies were $80 \cdot 2,81 \cdot 1,80 \cdot 2$ and $26 \cdot 1 \%$ respectively. After dialysing the supernatants from the urea and $\mathrm{NaCl}$ treatments overnight against distilled water, considerable degradation of $\mathrm{LH}$ was found to have occurred; by contrast, removal of formic acid by freeze drying resulted in extracts that yielded displacement curves parallel to authentic porcine LH in subsequent radioimmunoassay. As a result of these findings the following method was routinely applied. Receptor preparations $(0.5 \mathrm{ml}, 40-50 \mathrm{mg}$ protein) were acidified by addition of $5 \mathrm{ml}$ fresh, ice-cold $0.1 \mathrm{~N}$-formic acid $(\mathrm{pH} 2.4)$ and incubated overnight at $4^{\circ} \mathrm{C}$. Insoluble material was then sedimented by centrifugation at $10000 \mathrm{~g}$ for $25 \mathrm{~min}$ and supernatants were freeze dried. Residues after freeze drying were dissolved in $2 \mathrm{ml}$ radioimmunoassay buffer and assayed for $\mathbf{L H}_{\mathrm{C}}$ as described below 
Results were corrected for elution efficiency using values determined separately with ${ }^{125} \mathrm{I}$-labelled LH-receptor preparations (mean recovery $80 \%$ ). Porcine liver, spleen and kidney were used as blank tissues.

Radioimmunoassay of $\mathrm{LH}$ eluted from luteal receptors. $\mathrm{LH}$ concentration was estimated by double-antibody radioimmunoassay using LH-GPZ-1 as standard and for iodination as described by Ziecik et al. (1978). The samples were incubated in polystyrene test tubes; all additions were made in $50 \mathrm{mM}$-sodium phosphate, $\mathrm{pH} 7.4$, containing $0.15 \mathrm{M}-\mathrm{NaCl}, 0.01$ M-EDTA, $0.25 \%$ bovine serum albumin and $0.01 \%$ sodium azide. To each tube was added 0.1 $\mathrm{ml}$ buffer, $0.1 \mathrm{ml}$ standard porcine $\mathrm{LH}$ or unknown and $0.2 \mathrm{ml}$ anti-LH serum diluted to $1: 80000$ in assay buffer containing $0.5 \%$ normal rabbit serum. After $24 \mathrm{~h}$ at room temperature, $0.1 \mathrm{ml}{ }^{125}$ I-labelled LH (10 000 counts $\left.\mathrm{min}^{-1}\right)$ was added, followed after incubation for a further $24 \mathrm{~h}$ at room temperature, by $0.1 \mathrm{ml}$ second antibody (sheep anti-rabbit serum, 1:10 dilution). The reaction was interrupted after a further $20 \mathrm{~h}$ at room temperature by adding $1.5 \mathrm{ml}$ distilled water and centrifuging at $1000 \mathrm{~g}$ for $30 \mathrm{~min}$. Supernatants were decanted and pellets counted to determine ${ }^{125} I$ as described above.

The sensitivity of the assay was $0.15 \mathrm{ng} \mathrm{LH} / \mathrm{ml}$. Recoveries, determined by adding various amounts of LH $(0.3-10 \mathrm{ng})$ to luteal membrane preparations suspended in $5 \mathrm{ml} 0.1 \mathrm{~N}$-formic acid, varied from 88 to $116 \%$ (mean $100 \cdot 2 \%, 8$ determinations); plotting LH recovered $(y)$ against LH added $(x)$ gave $y=0.04+0.911 x$ by linear regression analysis (correlation coefficient, $r=0.990$ ). The same experiment carried out with a mixed cell membrane fraction from non-luteal control tissues gave $y=-0.25+0.989 x(r=0.996)$. Determination of the concentration of dissociated LH from membrane preparations of porcine liver, spleen and kidney

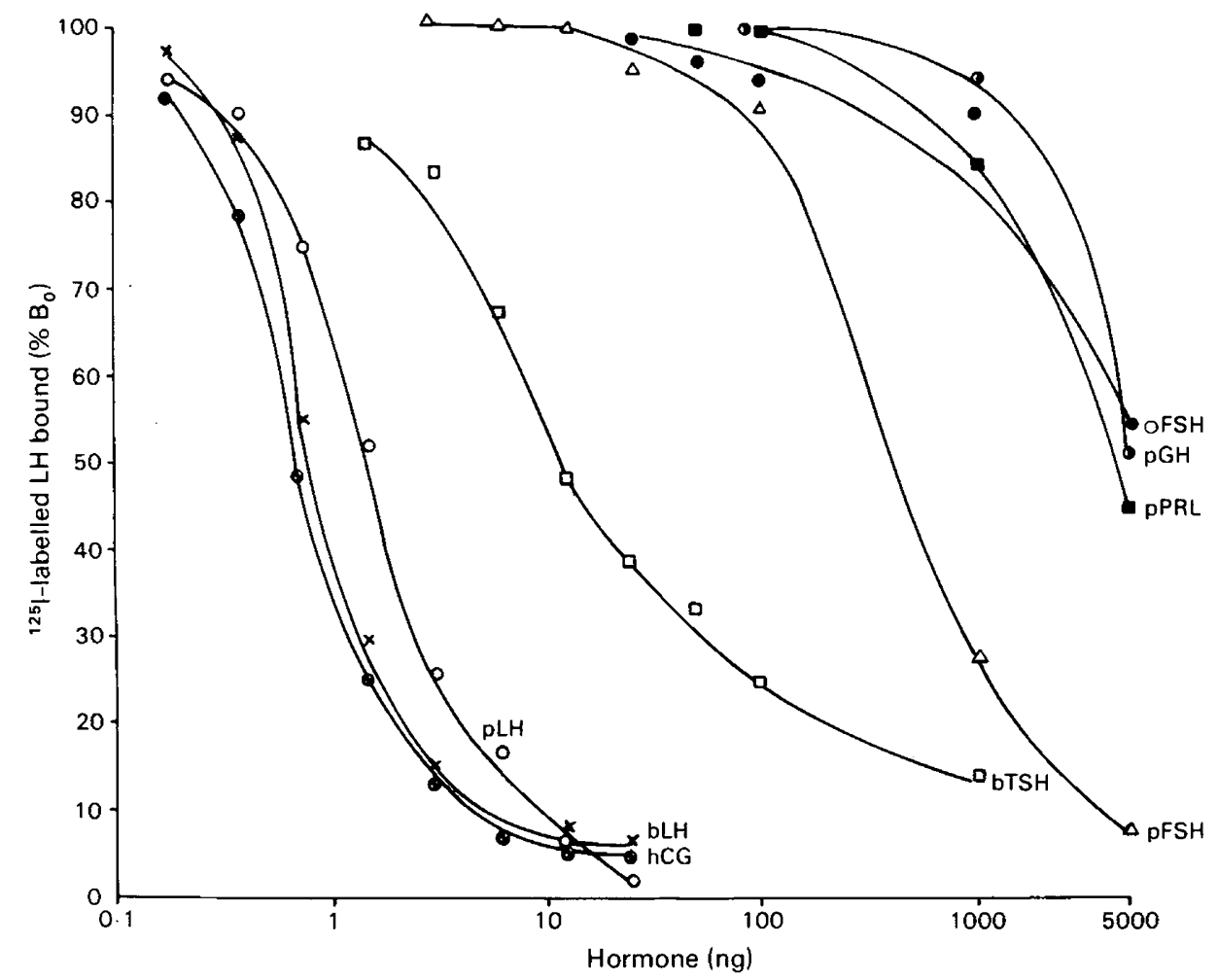

Text-fig. 1. Specificity of the luteal LH receptor; cross-reactions of pituitary hormones and hCG were determined by using ${ }^{125} \mathrm{I}$-labelled porcine $\mathrm{LH}$ as labelled ligand, with a mixed receptor sample from cyclic and pregnant sows. 


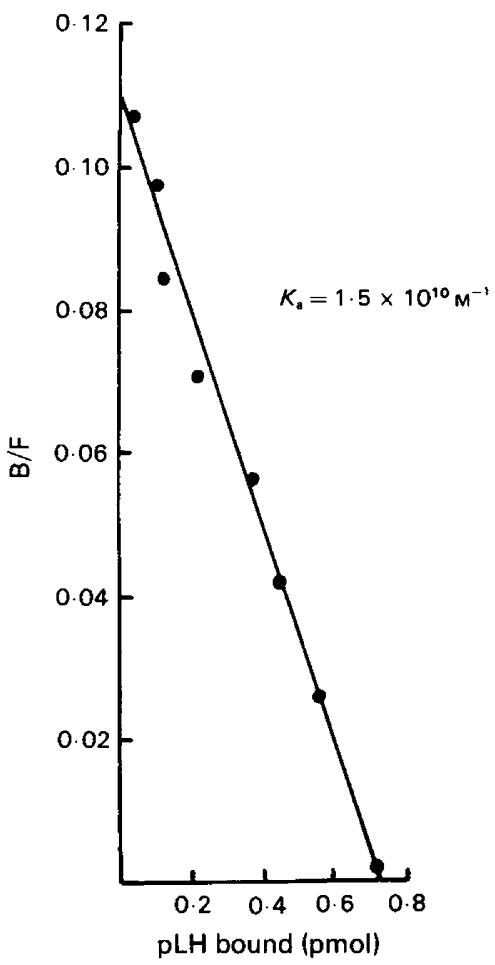

Text-fig. 2. Calculation of affinity constant by Scatchard analysis of binding data. The receptor preparation was from corpora lutea on Day 8 of the cycle. See text for details.

showed that endogenous $\mathrm{LH}$ was undetectable in liver and present in low concentrations $(<0 \cdot 1$ $\mathrm{ng} / \mathrm{mg}$ protein) in spleen and kidney. All measurements were made in triplicate; within-assay coefficient of variation was $4 \cdot 6 \%$ and between-assay coefficient of variation was $12 \cdot 3 \%$.

\section{Results}

\section{Specificity of $L H$ receptor}

Cross-reactions of various hormones with porcine LH are shown in Text-fig. 1. The inhibition of binding by hCG and ovine $\mathrm{LH}$ was greater than that obtained with unlabelled porcine $\mathrm{LH}$; this is consistent with the relatively low potency of the porcine $\mathrm{LH}$ used $(0.63 \times$ NIH-LH-S 1). The cross-reactivity of bovine TSH (12\%) can be accounted for by contamination with LH. Porcine and ovine FSH, which are structurally related to $\mathrm{LH}$, showed low cross-reactions $(<1 \%$ and $<0.04 \%$ respectively) and cross-reactivities of other hormones were negligible.

\section{Affinity constants}

Linear Scatchard plots were obtained for binding data (Text-fig. 2) at all stages of the cycle and pregnancy except on Days 12-14 of pregnancy, when binding appeared to be influenced by a lower affinity component not otherwise present. This was not investigated further. Affinity constants varied between 1.27 and $2.62 \times 10^{10} \mathrm{M}^{-1}$ during the oestrous cycle and between 0.75 and $1.63 \times 10^{10} \mathrm{M}^{-1}$ in early pregnancy (Table 1). The affinity of the receptor for LH increased slightly but significantly between Days 10 and 16 of the oestrous cycle, and decreased on 2 Day $15: 25$ PM 


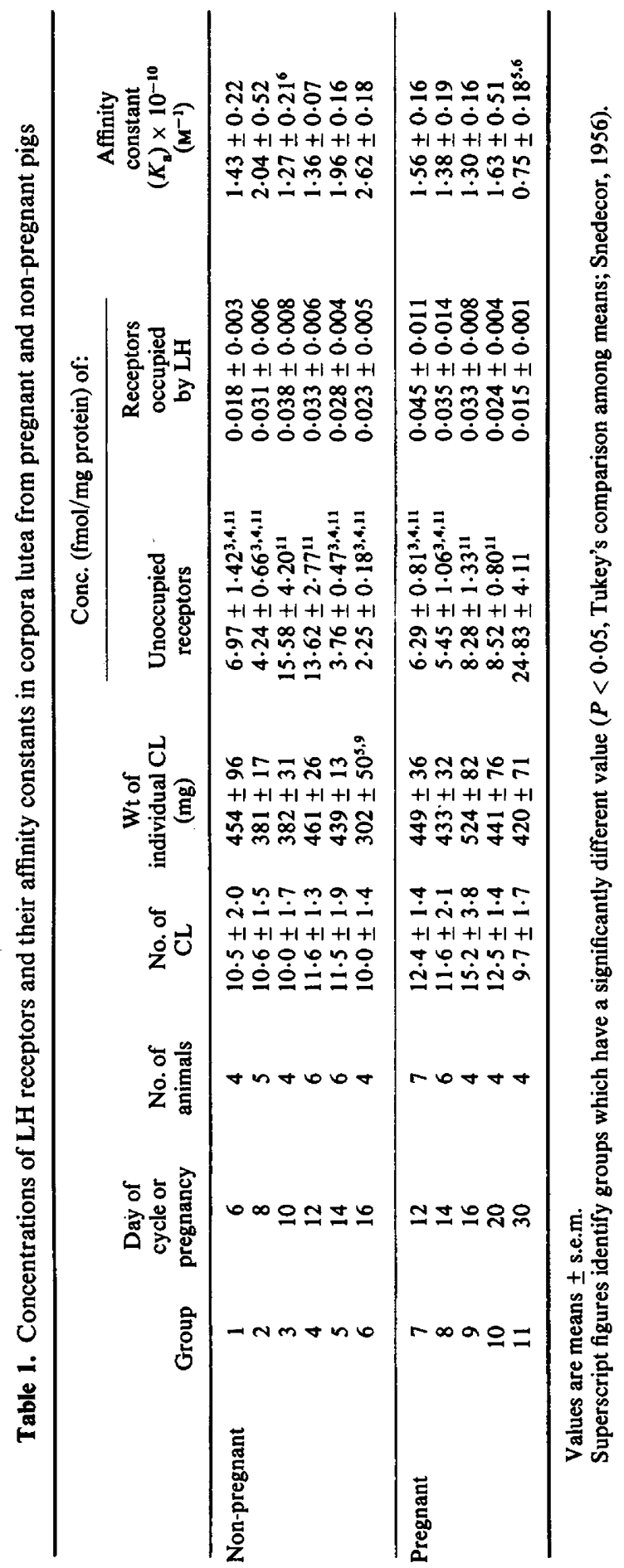


30 of pregnancy. These changes appeared to be inversely related to changes in receptor concentration; linear regression analysis of affinity constant $\left(\times 10^{-10}\right)(y)$ against unoccupied receptor concentration ( $\mathrm{fmol} / \mathrm{mg}$ protein) $(x)$ gave $y=-0.0788 x+2.85(r=-0.6543)$ for cyclic animals and $y=-0.0438 x+1.7869(r=-0.5633)$ during pregnancy.

\section{Receptor concentrations}

The concentration of unoccupied receptor increased approximately 2 -fold between Days 6 and 10 of the oestrous cycle; after Day 12 it decreased dramatically (Table 1). Occupied receptors represented a small proportion of the total $(0 \cdot 24-1.02 \%)$ during the cycle, and no significant changes were observed in the concentration of occupied receptors during the periods studied. In pregnancy the concentration of unoccupied receptors was lower on Day 12 than at a corresponding stage of the oestrous cycle; between Days 20 and 30 of gestation it increased 3 -fold. By contrast, the concentration of receptor occupied by LH was no lower on Day 12 of pregnancy than on Day 12 of the cycle, and appeared to decrease approximately 3-fold between Days 12 and 30. The increase in unoccupied receptor concentration between Days 12 and 30 of gestation was reflected in a decrease in the percentage of receptors occupied by LH (from 0.81 $\pm 0.24 \%$ on Day 12 to $0.07 \pm 0.01 \%$ on Day $30 ; P<0.05$ ).

\section{Discussion}

The measurement and characterization of the porcine luteal LH receptor during the oestrous cycle and early pregnancy has not been reported previously; however, the data on the specificity, affinity constant and occupancy of the receptors given here are comparable to those described for luteal LH receptors in other species (cow: Gospodarowicz, 1973; Papaionannou \& Gospodarowicz, 1975; ewe: Diekman et al., 1978a; man: Halme et al., 1978).

A difference between the present work and that of many authors is in our use of homologous porcine LH, rather than hCG, as labelled ligand and standard. Although ${ }^{125} \mathrm{I}$-labelled hCG is more stable than many preparations of iodinated LH (Channing \& Kammerman, 1974; Diekman et al., 1978a), we felt it important to use porcine LH because of the difference reported in affinity constants for hCG and LH with some receptors (see Papaionannou \& Gospodarowicz, 1975) and the possibility that the affinities of the LH receptor for hCG and LH may change independently during the cycle and in early pregnancy. Such a change has been noted in human corpora lutea by Halme et al. (1978). The LH preparation utilized in the present work has previously been used successfully in the investigation of the LH receptor in boar testis (Ziecik et al., 1978).

The unoccupied LH receptor concentration at Day 12 of pregnancy was lower than at a comparable stage of the cycle. This was unexpected since Days 11-13 of pregnancy are critical for the establishment of the corpus luteum of the cycle as the corpus luteum of pregnancy and the prevention of luteal regression, which normally starts at this time (see Flint, Burton, Gadsby, Saunders \& Heap, 1979). This decrease in early pregnancy may reflect down-regulation of receptor numbers (Bex \& Corbin, 1979; Catt, Harwood, Aguilera \& Dufau, 1979) because circulating $\mathrm{LH}$ concentrations are higher in early pregnancy than in the cycle (Guthrie, Henricks \& Handlin, 1972; A. Ziecik \& H. Krzymowska, unpublished observations). No such difference in luteal receptor numbers was found between pregnant and non-pregnant ewes on Day 12 after oestrus (Diekman et al., 1978a), but in sheep there is no comparable effect of gestation on plasma $\mathrm{LH}$ concentrations during the first 16 days of pregnancy (Niswender, Roche, Foster \& Midgley, 1968; Denamur, Kann \& Short, 1973). However, the concentration of receptors occupied by LH was not reduced in early pregnancy, and if, as Mendelson, Dufau \& Catt (1975) and Diekman et al. (1978a) have suggested, it is the occupied receptor $_{1}$ 
concentration which determines adenylate cyclase activity, no reduction in luteal progesterone production would be expected to result from the decreased unoccupied receptor concentration.

The unoccupied receptor concentration increased dramatically between Days 20 and 30 of pregnancy, while occupancy declined. There are a number of possible explanations for these changes. Luteal $\mathrm{LH}$ receptor concentrations are controlled in the rat by prolactin and placental lactogen (Gibori \& Richards, 1978), and the rise in luteal prolactin receptor concentration in the pig in pregnancy suggests a growing dependence on a lactogenic stimulus as pregnancy proceeds (Rolland et al., 1976). However, there is no placental lactogen in the pig (Kelly, Tsushima, Shiu \& Friesen, 1976; W. B. Currie, personal communication). Oestrogens, which are luteotrophic in the pig (Kidder, Casida \& Grummer, 1955; Gardner, First \& Casida, 1963) as in the rabbit and rat, appear in the maternal circulation in increasing concentrations between Days 20 and 30 of gestation (Robertson \& King, 1974), and may also be a stimulus to increased LH receptor concentrations. Oestrogens increase progesterone production by pig granulosa cells cultured in vitro (Goldenberg, Bridson \& Kohler, 1972) and stimulate ${ }^{123}$ I-labelled LH binding to dispersed porcine granulosa cells (Nakano et al., 1977).

The decrease in receptor occupancy between Days 20 and 30 of pregnancy may be due to the appearance in the circulation of a chorionic gonadotrophin-like hormone, which competes with LH for the luteal receptor, but does not assay as LH in the radioimmunoassay. A substance with these properties is present in extracts of early porcine conceptuses and in pig placenta (Saunders, Ziecik \& Flint, 1980), but it is not known whether this material appears in the maternal circulation. This decrease in occupancy may also reflect the decrease in the affinity of the receptor which occurs between Days 20 and 30 of gestation.

Luteal regression was preceded by a decline in the number of unoccupied LH receptors between Days 12 and 14 of the cycle; no comparable decline in occupied receptors occurred, and percentage occupancy therefore increased. This also occurs in the ewe during luteal regression induced by prostaglandin F-2 $\alpha$ (Diekman et al., 1978a). Porcine luteal adenylate cyclase is sensitive to LH on Day 14, but its activity declines and is lost on Days 16 to 18 of the cycle (Anderson, Schwartz \& Ulberg, 1974). The drop in unoccupied receptors observed here therefore preceded the decline in adenylate cyclase sensitivity, and may represent an early event in luteal regression.

We thank Mr K. Elsome and Dr C. Polge, Animal Research Station, Huntingdon Road, Cambridge, for providing experimental animals at known stages of the cycle and pregnancy, and Mrs N. Ackland and Miss P. T. K. Saunders for assistance. A.J.Z. received a British Council Bursary.

\section{References}

Anderson, R.N., Schwartz, F.L. \& Ulberg, L.C. (1974) Adenylate cyclase activity of porcine corpora lutea. Biol. Reprod. 10, 321-326.

Bex, F.H. \& Corbin, A. (1979) Mechanism of the postcoital contraceptive effect of luteinizing hormone-releasing hormone: ovarian luteinizing hormone interactions. Endocrinology 105, 139-145.

Catt, K.J. \& Dufau, M.L. (1975) Gonadal receptors for luteinizing hormone and chorionic gonadotrophin. Methods Enzymol. 37, 167-193.

Catt, K.J., Harwood, J.P., Aguilera, G. \& Dufau, M.L. (1979) Hormonal regulation of peptide receptors and target cell responses. Nature, Lond. 280, 109-116.

Chamness, G.C. \& McGuire, W.L. (1975) Scatchard plots: common errors in correction and interpretation. Steroids 26, 538-542.
Channing, C.P. \& Kammerman, S. (1974) Binding of gonadotrophins to ovarian cells. Biol. Reprod. 10, 179-198.

Denamur, R., Kann, G. \& Short, R.V. (1973) How does the corpus luteum of the sheep know that there is an embryo in the uterus? In Endocrinology of Pregnancy and Parturition: Experimental Studies in the Sheep, pp. 2-4. Ed. C. G. Pierrepoint. AlphaOmega-Alpha, Cardiff.

Diekman, M.A., O'Callaghan, P., Nett, T.M. \& Niswender, G.D. (1978a) Validation of methods and quantification of luteal receptors for $\mathrm{LH}$ throughout the estrous cycle and early pregnancy in ewes. Biol. Reprod. 19, 999-1009.

Diekman, M.A., O'Callaghan, P., Nett, T.M. \& Niswen-

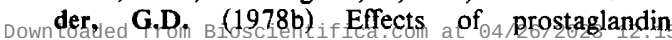


$F_{2 \alpha}$ on the number of LH receptors in ovine corpora lutea. Biol. Reprod. 19, 1010-1013.

Dufau, M.L., Catt, K.J. \& Tsuruhara, T. (1972) Biological activity of human chorionic gonadotropin released from testis binding-sites. Proc. natn. Acad. Sci. U.S.A. 69, 2414-2416.

Flint, A.P.F., Gadsby, J.E. \& Heap, R.B. (1979) Blastocyst steroids; their synthesis and action. In Research on Steroids, vol. 8, pp. 3-10. Eds A. Klopper, L. Lerner, H. J. van der Molen \& F. Sciarra. Academic Press, London.

Flint, A.P.F., Burton, R.D., Gadsby, J.E., Saunders, P.T.K. \& Heap, R.B. (1979) Blastocyst oestrogen synthesis and the maternal recognition of pregnancy. In Maternal Recognition of Pregnancy (Ciba Symp. No. 64), pp. 209-288. Ed. J. Whelan. Excerpta Medica.

Gardner, M.L., First, N.L. \& Casida, L.E. (1963) Effect of exogenous estrogens on corpus luteum maintenance in gilts. J. Anim. Sci. 22, 132-134.

Gibori, G. \& Richards, J.S. (1978) Dissociation of two distinct luteotropic effects of prolactin: regulation of LH-receptor content and progesterone secretion during pregnancy. Endocrinology 102, 767-774.

Goldenberg, R.L., Bridson, W.E. \& Kohler, P.O. (1972) Estrogen stimulation of progesterone synthesis by porcine granulosa cells in culture. Biochem. Biophys. Res. Commun. 48, 101-107.

Gospodarowicz, D. (1973) Properties of the luteinizing hormone receptor of isolated bovine corpus luteum plasma membranes. J. biol. Chem. 248, 5042-5049.

Greenwood, F.C., Hunter, W.M. \& Glover, J.S. (1963) The preparation of ${ }^{131}$ I-labelled human growth hormone of high specific radioactivity. Biochem. J. 89, 114-123.

Guthrie, H.D., Henricks, D.M. \& Handlin, D.L. (1972) Plasma estrogen, progesterone and LH prior to estrus and during early pregnancy in pigs. Endocrinology 91, 675-679.

Halme, J., Ikonen, M., Rutanen, E.M. \& Seppälä, M. (1978) Gonadotropin receptors of human corpus luteum during menstrual cycle and pregnancy. $A m . J$. Obstet. Gynec. 131, 728-734.

Hansel, W., Concannon, P.W. \& Lukaszewska, J.H. (1973) Corpora lutea of the large domestic animals. Biol. Reprod. 8, 222-245.

Henderson, K.M. \& McNatty, K.P. (1975) A biochemical hypothesis to explain the mechanism of luteal regression. Prostaglandins 9, 779-797.

Kammerman, S., Canfield, R.E., Kolena, J., Channing, C.P. (1972) The binding of iodinated hCG to porcine granulosa cells, Endocrinology 91, 65-74.

Kelly, P.A., Tsushima, T., Shiu, R.P.C. \& Friesen, H.G. (1976) Lactogenic and growth hormone-like activities in pregnancy determined by radioreceptor assays. Endocrinology 99, 765-774.

Kidder, W.E., Casida, L.E. \& Grummer, R.H. (1955) Some effects of estrogen injections on the estrual cycle of gilts. J. Anim. Sci. 14, 470-474.

Lee, C.Y. (1976) The porcine ovarian follicle. III. Development of chorionic gonadotropin receptors associated with increase in adenyl cyclase activity during follicle maturation. Endocrinology 99, 42-48.

Lemon, M. \& Loir, M. (1977) Steroid release in vitro by two luteal cell types in the corpus luteum of the pregnant sow. J. Endocr. 72, 351-359.

Lowry, O.H., Rosebrough, N.J., Farr, A.L. \& Randall, R.J. (1951) Protein measurement with the folin phenol reagent. J. biol. Chem. 193, 265-275.

Mendelson, C., Dufau, M. \& Catt, K. (1975) Gonadotropin binding and stimulation of cyclic adenosine $3^{\prime}: 5^{\prime}$-monophosphate and testosterone production in isolated Leydig cells. J. biol. Chem. 250, 8818-8823.

Nakano, R., Akahori, T., Katayama, K. \& T.ojo, S. (1977) Binding of LH and FSH to porcine granulosa cells during follicular maturation. J. Reprod. Fert. 51, 23-27.

Nalbandov, A.V. (1973) Control of luteal function in mammals. In Handbook of Physiology, Endocrinology II, Part I. pp. 153-167. Eds R. O. Greep \& E. B. Astwood. Am. Physiol. Soc., Washington. D.C.

Niswender, G.D., Roche, J.F., Foster, D.L. \& Midgley, A.R. (1968) Radioimmunoassay of serum levels of luteinizing hormone during the cycle and early pregnancy in ewes. Proc. Soc. exp. Biol. Med. 129, 901-904.

Niswender, G.D., Menon, K.M.H. \& Jaffe, R.B. (1972) Regulation of the corpus luteum during the menstrual cycle and early pregnancy. Fert. Steril. 23, 432-442.

Papaionannou, S. \& Gospodarowicz, D. (1975) Comparison of the binding of human chorionic gonadotropin to isolated bovine luteal cells and bovine luteal plasma membranes. Endocrinology 97, 114124.

Reichert, L.E. \& Jiang, N.S. (1965) Comparative gel filtration and density gradient centrifugation studies on heterologous pituitary luteinizing hormones. Endocrinology 77, 78-86.

Robertson, H.A. \& King, G.J. (1974) Plasma concentrations of progesterone, oestrone, oestradiol- $17 \beta$ and of oestrone sulphate in the pig at implantation, during pregnancy and at parturition. J. Reprod. Fert. 40, $133-141$.

Rolland, R., Gunsalus, G.L. \& Hammond, J.M. (1976) Demonstration of specific binding of prolactin by porcine corpora lutea. Endocrinology 98, 10831091.

Saunders, P.T.K., Ziecik, A.J. \& Flint, A.P.F. (1980) Gonadotrophin-like substance in pig placenta and embryonic membranes. J. Endocr. 85, $25 P$.

Snedecor, G.W. (1956) Statistical Methods, 5th edn. Iowa State College Press, Ames, Iowa.

Watson, J. \& Leask, J.T.S. (1975) Superfusion in vitro in the study of ovarian steroidogenesis. J. Endocr. 64, $163-173$.

Ziecik, A., Goralska, M., Krzymowski, T. \& Pogorzelski, K. (1978) Isolation and purification of porcine LH for radioimmunoassay and radioreceptor assay. Bull. Acad. pol. Sci. Cl. II Ser. Sci. biol. 26, 739-744. 